RAD Conference Proceedings, vol. 2, pp. 155-158, 2017

www.rad-proceedings.org

\title{
GENETIC STABILITY OF HUMAN MESENCHYMAL STEM CELLS EXPOSED TO X-RAYS OR HEAT SHOCK IN CULTURE
}

\author{
Mariia Shilina $^{*}$, Zoya Kovaleva' ${ }^{1}$, Nikolay Nikolsky², Tatiana Grinchuk ${ }^{1}$
}

${ }^{1}$ Group of Genetic Mechanisms of Cell Differentiation and Malignization, Institute of Cytology, Russian Academy of Science, St. Petersburg, Russia

${ }^{2}$ Department of Intracellular Signalling and Transport, Institute of Cytology, Russian Academy of Science, St. Petersburg, Russia

\begin{abstract}
The aim of this study was to investigate the cytogenetic assay of endometrial mesenchymal stem cells $(e M S C)$ in vitro after the exposure to a sublethal dose of X-rays and the sublethal heat shock (HS). For the analysis of chromosomes, we used the G-banding technique. We showed that both types of stress caused similar changes in eMSC karyotype structure. In both cases, 80\% of the cell population had karyotype abnormalities. The main types of rearrangements were aneuploidy and chromosomal breaks. Chromosomes 1 and 4 were involved in breaks more often than other chromosomes. The number of chromosomes involved in the restructuring as a result of HS was larger than after $X$-rays.
\end{abstract}

Key words: Human stem cells, irradiation, $X$-rays, heat shock

DOI: $10.21175 / \operatorname{RadProc} .2017 .31$

\section{INTRODUCTION}

The study of eMSC stress response expands our knowledge on the stem cell biology.

The number, size and chromosome structure are species-specific characteristics. The frequency of genetic material changes in populations depends on their living conditions. Deviations from the normal karyotype are adaptive in nature. The organism adaptation to environmental changes is accompanied with the occurrence of karyotypic instability. The most studied exogenous stress factors are ionizing radiation, chemical agents and changes of temperature. The optimal temperature range varies for different organisms, but, despite of this, protective mechanisms are very conservative. It has been found that cell response to heat stress depends on the stress intensity and duration as well as on the cell type. A slight increase in temperature leads to apoptosis or premature aging of cells, whereas the increased temperature causes the necrotic death [1]. The cellular response to hyperthermia is accompanied with the accumulation of heat shock proteins, impaired cell division and karyotype anomalies [2]-[4].

Another type of exogenous stress, which can lead to changes in the structure of the cell genome, is ionizing radiation. X-rays and gamma radiation alter the DNA organization. Changes in the DNA structure are the basis of mutagenic and carcinogenic effects of irradiation frequently manifested in chromosome rearrangements. Chromosomal aberrations in cells morphologically appear mainly in chromosomal damage [5]-[8]. Some researchers found that the increase in radiation dose raised the number of chromosomal aberrations [9], [10].

In this study, we compared the pattern of karyotypic changes induced in eMSC exposed to heat shock and X-rays.

\section{MATERIALS AND METHODS}

Cell culture. The line of human endometrial mesenchymal stem cells was maintained by the standard protocol in DMEM/F12 (Gibco, United States) with $10 \%$ bovine fetal serum (HyClone, United States), 1\% antibiotic-antimycotic solution and 1\% GlutaMAX (Gibco, United States). The cells were subcultured 1:3-1:4 twice a week using $0.05 \%$ trypsin/EDTA (Invitrogen, United States) [11].

$X$-rays. The eMSC at the 9 th passage were irradiated with the sublethal dose of X-rays (5Gy). Irradiated cells were cultivated under standard conditions and, at the 13th passage, they underwent the karyotyping assay with the G-banding technique.

Heat shock. The eMSC at the 6th passage were exposed to a sublethal heat shock $\left(45^{\circ} \mathrm{C}\right.$ for $\left.30 \mathrm{~min}\right)$. After HS cells were cultivated under standard conditions and, at the 12th passage, they underwent the karyotyping assay with the G-banding technique.

* shili-mariya@yandex.ru 
G-banded karyotyping was performed according to the standard protocol. The cells were seeded with the density of $14-15 \times 10^{3}$ cells $/ \mathrm{cm}^{2}$. The mitostatic agent colcemid (stock solution $10 \mathrm{mg} / \mathrm{mL}$ ) (Sigma, United States) was added after $24-25 \mathrm{~h}$ cultivation for $1 \mathrm{~h}$. Then the medium was removed, cells were treated with $0.05 \%$ trypsin and centrifuged. The pellet was suspended and treated with $0.56 \% \mathrm{KCl}$ hypotonic solution for about $1 \mathrm{~h}$. The cell suspension was centrifuged (1300 rpm), resuspended and fixed on ice by methanol mixed with acetic acid 3:1. The fixator was changed three times, total fixation time was $1.5 \mathrm{~h}$. The fixed material was dropped on cold and wet slides. The slides were air-dried for one week. Chromosomes were G-banded with Giemsa stain (Fluka, United States) after preliminary trypsinization (Biolot, Russia). Metaphase plates were assayed under the microscope Axio Scop (Carl Zeiss, Germany), objective 100×, ocular $20 \times$. The chromosomes were identified according to the international nomenclature [12] and atlas of human chromosomes [13].

$S A-\beta$-Gal activity. The enzyme activity is a marker of cellular senescence. $10^{5}$ cells were plated in $3-\mathrm{cm}$ Petri dishes and cultivated for 3 days. Then the medium was removed, cells were washed with PBS, fixed with $4 \%$ formaldehyde and stained with senescence-galactosidase staining kit (Cell Signaling, United States) according to the manufacturer's instructions. SA- $\beta$-Gal activity was detected by cell blue staining visualized under a microscope.

\section{RESULTS AND DISCUSSION}

We have provided evidence that both types of stress induce changes in the structure of eMSC karyotype. In both cases, $80 \%$ of the cell population had karyotype disorders. The main types of rearrangements were aneuploidy and chromosomal breaks. The number of copy aneuploid cells varied ranged from 1 to 3 . These changes are typical for cells with the impaired cell division [14]-[16]. Chromosome breaks occurred in both near- and distal-centromere areas. However, the number of chromosomes involved in breaks was different after HS and X-rays. Chromosome breaks were registered more often in chromosomes 1,4 , and X (irradiation) and 1, 2, 3, 4, 5 (heat shock). These findings show that chromosomes 1 and 4 were the most fragile in cells exposed both to HS and X-rays (see Figure 1,2). The increased sensitivity of chromosome 1 was also found in the study of the effect of heat shock on human cell lines [17], [18]. The increased sensitivity of chromosome 4 was typical for human cells after $\mathrm{X}$-rays [19]-[22].

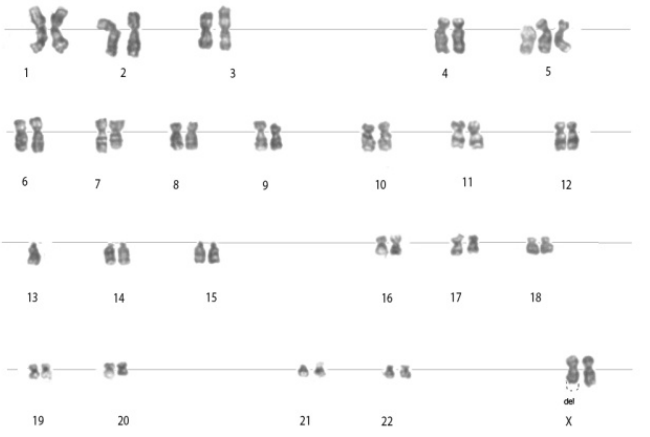

Figure 1. Karyotype eMSC $4^{\text {th }}$ passage after X-ray irradiation. In total, cells have gone through 13 passages. Trisomy and near-centromere breakage of chromosome 5 ; deletion of chromosome X, monosomy of chromosomes 13 .

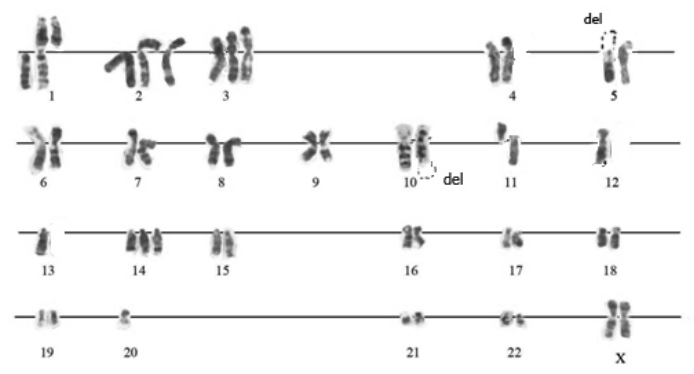

Figure 2. Karyotype eMSC 6th passage after HS. In total, cells have gone through 12 passages. Near-centromere breakage of chromosomes 1, 5, 11; distal deletion of chromosome 10; trisomy of chromosomes $2,3,14$; monosomy of chromosomes $11,12,13,20$.

The eMSC exposed to both stress types entered replicative senescence (see Figure 3).

Collectively, eMSC survived after HS or X-ray irradiation, entered replicative senescence and died, avoiding immortalization and transformation. 

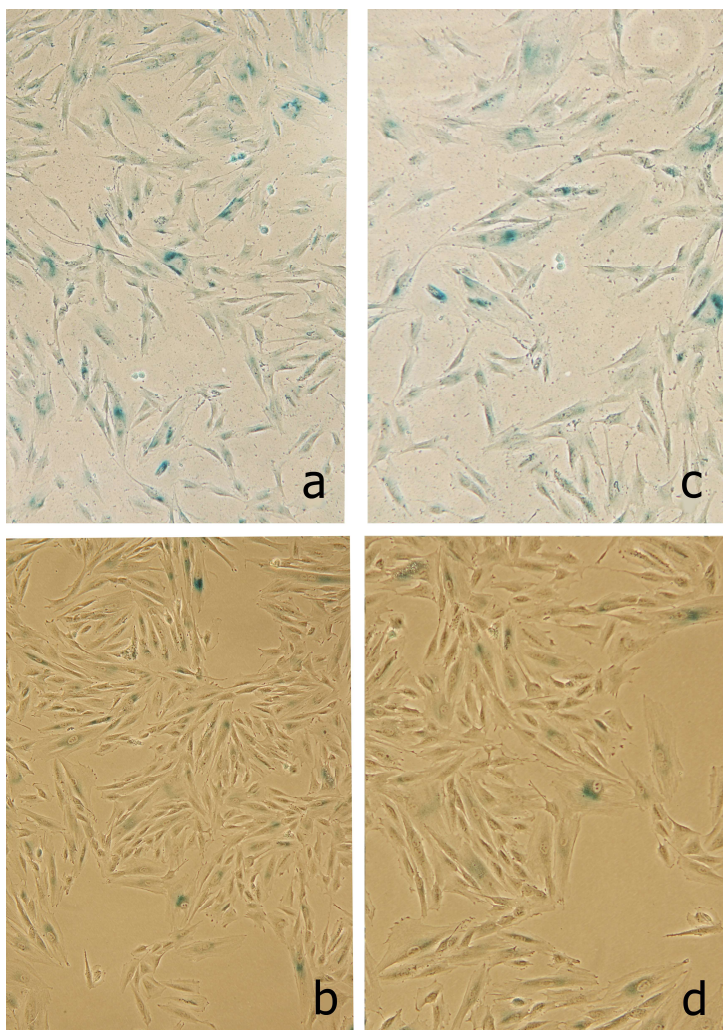

Figure 3. SA- $\beta$-Gal staining. A - long-term cultivation of eMSC survived X-ray; B - eMSC survived X-ray on 2 passage after irradiation; $\mathrm{C}$ - long-term cultivation of eMSC survived HS ; D - eMSC survived HS on 3 passage after temperature treatment.

This work has no analogues.

Acknowledgement: The paper is a part of the research done within the project 14-50-00068 (by Russian Scientific Foundation).

\section{REFERENCES}

1. B. V. Harmon, A. M. Corder et al., "Cell death induced in a murine mastocytoma by $42-47$ degrees $\mathrm{C}^{\circ}$ heating in vitro: evidence that the form of death changes from apoptosis to necrosis above a critical heat load," Int. J. Radiat. Biol., vol. 58, no. 5, pp. 845 - 858, May 1990. DOI: $10.1080 / 09553009014552221$ PMid: 1977828

2. R. K. Gupta, U. K. Srinivas, "Heat shock induces chromosomal instability in near-tetraploid embryonal carcinoma cells," Cancer Biol. Ther., vol. 7 no. 9, pp. $1471-1480$, Sep. 2008

DOI: $10.4161 /$ cbt.7.9.6428 PMid: 18769133

3. L. L. Alekseenko, V. I. Zemelko et al., "Heat shock induces apoptosis in human embryonic stem cells but a premature senescence phenotype in their differentiated progeny," Cell Cycle, vol. 11, no. 17, pp. $3260-3269$, Aug. 2012.

DOI: $10.4161 / \mathrm{cc} .21595$

PMid: 22895173

PMCid: PMC3466525

4. T. M. Grinchuk, M. A. Shilina, L. L. Alekseenko, "Longterm cultivation of Chinese hamster fibroblasts V-79 RJK under elevated temperature results in karyotype destabilization," Cell and Tissue Biology, vol. 9, no. 2, pp. 119 - 126, Mar. 2015
DOI: 10.1134/S1990519X15020078

5. L. Stoilov, M. Georgieva, V. Manova, L. Liu, K. Gecheff, "Karyotype reconstruction modulates the sensitivity of barley genome to radiation-induced DNA and chromosomal damage," Mutagenesis, vol. 28, no. 2, pp. $153-160$, Mar. 2013.

DOI: 10.1093/mutage/geso65

PMid: 23221036

6. M. Nakano, Y. Kodama et al., "Detection of stable chromosome aberrations by FISH in A-bomb survivors: Comparison with previous solid Giemsa staining data on the same 230 individuals," International Journal of Radiation Biology, vol. 77, no. 9, pp. 971 - 977, Sep. 2001.

DOI: $10.1080 / 09553000110050065$

PMid: 11576457

7. Y. Kodama, D. Pawel, et al., "Stable chromosome aberrations in atomic bomb survivors: Results from 25 years of investigation," Radiation Research, vol. 156, no. 4, pp. $337-346$, Jun. 2001

DOI: $10.1667 / 0033-$ 7587(2001)156[0337:SCAIAB]2.0.CO;2

8. K. Ohtaki, Y. Kodama et al., "Human fetuses do not register chromosome damage inflicted by radiation exposure in lymphoid precursor cells except for a small but significant effect at low doses," Radiat. Res. vol. 161 , no. 4, pp. 373 - 379, Oct. 2004

DOI: $10.1667 / 3147$ PMid: 15038761

9. P. Bhatti, M. M. Doody, "Increased frequency of chromosome translocations associated with diagnostic X-ray examinations," Radiat. Res., vol. 170, no. 2, pp. $149-155$, Aug. 2008.

DOI: $10.1667 / R R 1422.1$

PMid: 18666821 PMCid: PMC2766815

10. C. Plamadeala, A. Wojcik, C. Dorina, "Micronuclei versus chromosomal aberrations induced by X-ray in radiosensitive mammalian cells," Iran J. Public Health, vol. 44, no. 3, pp. 325 - 331, 2015.

PMid: 25905075

PMCid: PMC4402410

11. В.И. Земелько, Т. М. Гринчук и другие, "Мультипотентные мезенхимные стволовые клетки десквамированного эндометрия. Выделение, характеристика и использование в качестве фидерного слоя для культивирования эмбриональных стволовых линий человека," Цитология, т. 53, но. 12, стр. 919 - 929, 2011 (V. I. Zemel'ko, T. M. Grinchuk et al., "Multipotent mesenchymal stem cells of desquamated endometrium: isolation, characterization and use as feeder layer for maintenance of human embryonic stem cell lines," Tsitologiya, vol. 53, no. 12, pp. 919 - 929, 2011.) PMid: 22359950

12. С. Е. Мамаева, Атлас хромосом постоянных клеточных линий человека и животных, Москва, Россия: Научный Мир, 2002. (S. Е. Mamaeva, Atlas chromosomes permanent cell lines of human and animals, Moscow, Russia: Sci. World, 2002.)

13. ISCN 1995: an International system for human cytogenetic nomenclature, F. Mitelman, Ed., Basel, Switzerland: Karger, 1995.

14. G. J. Todaro, H. Green, "Quantitative studies of the growth of mouse embryo cells in culture and their development into established lines," J. Cell Biol., vol. 17, no. 2, pp. $299-313$, May, 1963.

DOI: $10.1083 /$ jcb.17.2.299

PMid: 13985244 PMCid: PMC2106200

15. S. R. Romanov, B. K. Kozakiewicz, "Normal human mammary epithelial cells spontaneously escape senescence and acquire genomic changes," Nature, vol. 409, no. 6820, pp. 633 - 637, Feb. 2001.

DOI: $10.1038 / 35054579$

PMid: 11214324 
16. F. Miura, N. Kawaguchi, "A large-scale full-length cDNA analysis to explore the budding yeast transcriptome," Proc. Natl. Acad. Sci. USA, vol. 103, no. 47, pp. 17846 - 17851, Nov. 2006.

DOI: $10.1073 /$ pnas.0605645103

PMid: 17101987

PMCid: PMC1693835

17. N. I. Enukashvily, R. Donev, I. S. R. Waisertreiger, O. I. Podgornaya, "Human chromosome 1 satellite 3 DNA is decondensed, demethylated and transcribed in senescentcells and in A431 epithelial carcinoma cells," Cytogenetic and Genome Research, vol. 118, no. 1, pp. $42-54$, Sep. 2007.

DOI: $10.1159 / 000106440$

PMid: 17901699

18. A. Eymery, M. Callanan, C. Vourc'h, "The secret message of heterochromatin: New insights into the mechanisms and function of centromeric and pericentric repeat sequence transcription," Int. J. Dev. Biol., vol. 53, no. 2-3, pp. 259- 268, 2009.

DOI: $10.1387 / \mathrm{ijdb} .082673 \mathrm{ae}$ PMid: 19412885

19. S. Knehr, H. Zitzelsberger, H. Braselmann, U. Nahrstedt, M. Bauchinger, "Chromosome analysis by fluorescence in situ hybridisation: further indications for a non-DNA-proportional involvement of single chromosomes in radiation-induced structural aberrations," Int. J. Radiat. Biol., no. 70, no. 4, pp. 385 - 392, Oct. 1996.

DOI: $10.1080 / 095530096144851$

PMid: 8862449
20. J. J. W. A. Boei, S. Vermeulen, A. T. Natarajan, "Different involvement of chromosomes 1 and 4 in the formation of chromosomal aberrations in human lymphocytes after X-irradiation,” Int. J. Radiat. Biol., vol. 72, no. 2, pp. 139 - 145, Aug. 1997.

DOI: $10.1080 / 095530097143356$

PMid: 9269306

21. G. Stephan, S. Pressl, "Chromosome aberrations in human lymphocytes analysed by fluorescence in situ hybridisation after in vivo irradiation, and in radiation workers, 11 years after an accidental radiation exposure," Int. J. Radiat. Biol., vol. 71, no. 3, pp. 293 299, Mar. 1997.

DOI: $10.1080 / 095530097144175$

PMid: 9134019

22. А. Н. Богомазова, "Изучение стабильных и нестабильных хромосомных аберраций у лиц, пострадавших в результате аварии на ЧАЭС, в отдаленный пострадиационный период," Канд. наук диссертация, МЗ РФ Центр рентгенорадиологии, Санкт-Петербург, Россия, 200о. (А. N. Bogomazova "The study of stable and unstable chromosomal aberrations in persons affected by the Chernobyl accident in the remote post-radiation period," Sci. Can Dissirtation, MH RF Center for X-Ray Radiography, St-Petersburg, Russia, 2000.) 